\title{
Greenland marine-terminating glacier area changes: 2000-2010
}

\author{
Jason E. BOX, ${ }^{1,2}$ David T. DECKER ${ }^{2}$ \\ ${ }^{1}$ Department of Geography, The Ohio State University, 1036 Derby Hall, 154 North Oval Mall, Columbus, \\ Ohio 43210-1361, USA \\ E-mail: box11@osu.edu \\ ${ }^{2}$ Byrd Polar Research Center, The Ohio State University, 1090 Carmack Road, Columbus, OH 43210-1002, USA
}

\begin{abstract}
Area changes at 39 of the widest Greenland marine-terminating glacier outlets are measured in consecutive annual end-of-melt-season Moderate Resolution Imaging Spectroradiometer (MODIS) scenes spanning ten annual intervals (2000-10). The rates of cumulative area change for glaciers and ice shelves are well represented by linear least-squares fits, $R=-0.99$ and $R=-0.94$, with average rates of -70 and $-65 \mathrm{~km}^{2} \mathrm{a}^{-1}$, respectively. Collectively, during this decade, the 39 glaciers lost a cumulative area of $1368 \mathrm{~km}^{2}$. More than three-quarters of the total area change occurred north of $72^{\circ} \mathrm{N}$. The largest 11-year area change for a single glacier during the survey period is the $311 \mathrm{~km}^{2}$ loss at Humboldt Glacier. The largest annual change for a single glacier was extreme compared with the others, where Petermann glacier retreated $17 \mathrm{~km}$ between 3 and 5 August 2010. For the 10 year sample, on average, the count of glaciers retreating is twice that advancing. A larger distinction is evident considering area change, with the ratio of retreat and advance, on average, nine times the gain. For glaciers with ice shelves, we find no year with collective area gain. The area change data from this study are posted at: http://bprc.osu.edu/ jbox/data/GAC/
\end{abstract}

\section{INTRODUCTION}

Marine-terminating glaciers are a major conduit of mass loss from the ice-sheet system (Joughin and others, 2008a; Pfeffer and others, 2008). Changes at the fronts of marine-terminating outlet glaciers effect flow speed variations by modulating the balance of driving and resistive stresses (Meier and Post, 1987; Joughin and others, 2008a). The Greenland ice sheet annual mass deficit has grown substantially during the past two decades (Rignot and others, 2008). Abrupt glacier flow acceleration has been attributed to loss of bed traction from thinning and retreat of the calving fronts (Krabill and others, 2004; Thomas, 2004; Luckman and others, 2006; Howat and others, 2007; Joughin and others, 2008b; Nick and others, 2009). Rapid thinning prior to retreat has been linked with enhanced submarine melting due to the incursion of warm ocean currents (Holland and others, 2008). Multi-year retreats may be triggered in single anomalous years (Howat and others, 2010) followed by a multi-year dynamic response that includes thinning-induced inland grounding-line migration and upstream steepening of the surface slope, increasing driving stresses (Howat and others, 2005).

While submarine melting can occur at a much higher rate than at the surface-atmosphere interface (Motyka and others, 2003; Rignot and others, 2010), it is not necessarily the only significant factor influencing glacier front stability. Stability is also influenced by the winter consolidation of calf ice and landfast sea ice, leading to post-melt-season advance (Amundson and others, 2010; Howat and others, 2010). The advanced area is typically lost through rapid calving and retreat at the onset of the melt season. At Greenland's most productive glacier, Jakobshavn glacier (also known as Jakobshavn Isbræ or Sermeq Kujatdleq) (Weidick and Bennike, 2007), the interannual cycle in calving-front position exceeded $4 \mathrm{~km}$ (Sohn and others, 1998). Reeh and others (2001) and Joughin and others (2008a) earlier evaluated the importance of glacier front ice consolidation to glacier front stability. Seasonal retreat and advance causes an annual velocity cycle for some western Greenland marine-terminating glaciers (Joughin and others, 2008b). Several other marine-terminating glaciers in Greenland exhibit a smaller seasonal advance/retreat than Jakobshavn Isbræ, usually $<1 \mathrm{~km}$ in the case of glaciers near the settlement of Uummannaq, West Greenland (Howat and others, 2010). Inland ice-sheet flow accelerates more than $100 \%$ during active surface melt (Zwally and others, 2002; Van de Wal and others, 2008; Shepherd and others, 2009). Greenland melt rates have increased substantially since a multidecadal minimum in the mid-1980s (Box and others, 2006, 2009). Surface melting in the Arctic is projected to increase, driven not only by increasing atmospheric heat content, but by polar amplification of warming resulting from ice-albedo feedback (Solomon and others, 2007). Ocean heat content increases have been observed in Baffin Bay during the period 1916-2003 (Zweng and Münchow, 2006) and elsewhere throughout the global oceans in past decades (Levitus and others, 2009). Thus, in recognition of multiple forcings, the most likely scenario is that the ice-sheet mass budget deficit will continue to grow, contributing to global sea-level rise.

Moon and Joughin (2008) surveyed area changes at the 182 Greenland ice sheet outlet glaciers of at least $2 \mathrm{~km}$ width. The majority of these glaciers are marine-terminating and six are noted to have terminal ice shelves, namely Petermann, Zacharì̀, Nioghalvfjerdsbrì/79, Ostenfeld, Jakobshavn and Ryder. They found that the 2000-06 period was characterized by significant area losses while the earlier period 1992-2000 exhibited a more stable pattern. All of the glaciers advancing in 1992-2000 began retreating during 2000-06. Moon and Joughin (2008) associate the area losses with an increase in summer near-surface air temperatures. They also point to an emerging recognition of submarine melting (Rignot and Jacobs, 2002; Thomas, 2004) in potentially destabilizing glaciers. Further, they implicate a potential role of decreasing sea-ice extent or increased hydrofracture and calving from meltwater on the surface to explain the increase in retreat.

Howat and Eddy (2011) measured area changes at 210 marine Greenland glaciers in Landsat imagery spanning the 


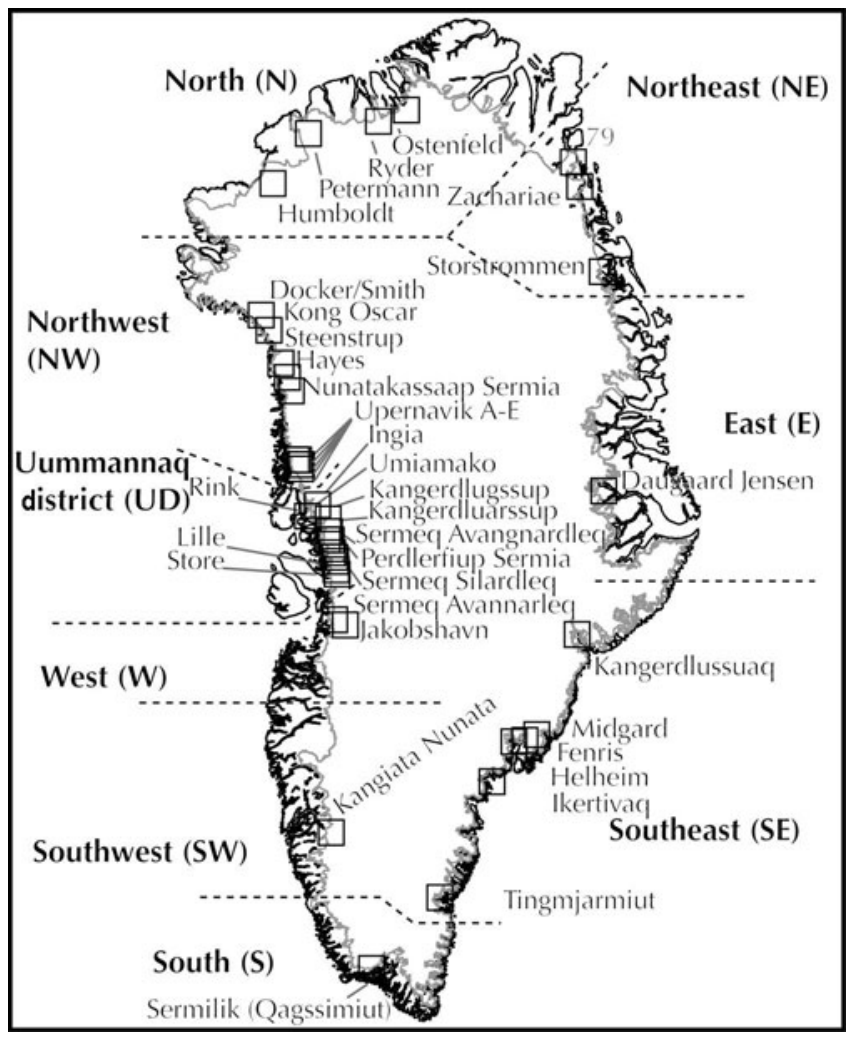

Fig. 1. Greenland location map showing the surveyed glaciers. Regional divisions are bracketed by dashed lines.

early 1970 s to 2010 . They found that the magnitude and extent of retreat increased in the early 1990s, coincident with the onset of warming following several decades of cooling and glacier stability. The results suggest that retreat over the decade 2000-10 is the most extensive in Greenland in the past half-century and possibly since the Little Ice Age (LIA). That study, however, did not resolve sub-decadal variability in front position. Moon and Joughin (2008) note that there was a significant decrease in southeast Greenland retreat in the mid-2000s. Yet, it remains unclear whether glacier retreat has accelerated during the decade or whether much of the retreat occurred during a single short-lived episode early in the decade and has largely subsided.

In this study, the area changes at the 39 widest marineterminating glacier outlets to the Greenland ice sheet are measured each year in the period 2000-10 using end-ofmelt-season Moderate Resolution Imaging Spectroradiometer (MODIS) imagery. Cumulative changes and trends are evaluated on individual glacier, regional and wholeisland scales. In the analysis, some distinction is made between glaciers with known ice shelves and those without.

\section{DATA AND METHODS}

\section{Optical imagery}

NASA MODIS $0.25 \mathrm{~km}$ resolution band $1(620-670 \mathrm{~nm})$ and band $2(841-876 \mathrm{~nm})$ MOD02 product imagery from the Terra satellite beginning in the year 2000 are used in this study to classify the position of glacier fronts. The MOD03 geolocation product is incorporated via the MODIS Swathto-Grid Toolbox (MS2GT) (http://nsidc.org/data/modis/ $\mathrm{ms} 2 \mathrm{gt} /$ ) to project the data onto a $0.25 \mathrm{~km}$ azimuthal EqualArea Scalable Earth Grid (EASE-Grid). In recognition of a potential annual cycle in front position (discussed above), we choose images from the end of the melt season. These occupy a 43 day period, 17 August to 29 September. MODIS data have the advantage of much more frequent ( daily) coverage than higher-resolution sensors such as Landsat or ASTER.

Area change is classified manually using spatial patterns in reflectance and texture in polygons relative to an arbitrary line beyond the glacier front and constrained by the fjord sides, similar to the approach of Moon and Joughin (2008). Consecutive annual polygons are differenced to quantify interannual area change. This area classification was repeated three or five times on the same image pairs to evaluate uncertainty. In the $>400$ repeat samples, we find that the interannual area changes exceed two standard deviations of the repeat samples $\left(1.0 \mathrm{~km}^{2}\right)$ in $63 \%$ of cases. The absolute accuracy of the classification depends on decisions by the person who distinguishes between glacier ice, calf ice, sea ice, clouds, sea and land. In ideal cases when there is little or no sea ice, the accuracy approaches the measurement precision. In marginal cases when images are blurry, have cloud contamination, shadows from land, and a less distinct calving front owing to increasing sea-ice concentration, the absolute accuracy is low $\left(<10 \mathrm{~km}^{2}\right)$. A glacier area increase, an advance, is given a positive sign. Conversely, negative values here represent glacier retreat. Effective glacier length changes were determined by dividing the area change by the glacier width measured at the year 2000 front.

All glaciers in the survey are marine-terminating. Our annual survey contains $30 \%(421 \mathrm{~km})$ of total glacier width $(1417 \mathrm{~km})$ or 39 of the $261(15 \%)$ marine-terminating glaciers of at least $1 \mathrm{~km}$ width. The relatively small fraction of the total count results from the fact that we select the widest glaciers where relatively large area changes are resolvable; essentially where the signal-to-noise ratio is highest and where calving rates are greatest (Weidick and Bennike, 2007). We find no correlation $(R=0.05)$ between glacier width and the effective glacier length change (area change divided by width). We may therefore conclude that we do not incur a sampling bias by preferentially measuring the widest glaciers.

Like Moon and Joughin (2008), we treat the six glaciers with extensive ice shelves (named above) separately from the other glaciers because the buttressing effects of ice shelves (e.g. De Angelis and Skvarca, 2003) seem to offer distinct situations. The name, position, width and geographic region of the glaciers surveyed are listed in Table 1. Figure 1 illustrates the glacier positions, names and regions chosen for discussion.

\section{AREA CHANGES}

\section{Individual and regional glacier changes}

The largest cumulative area changes occur in northern Greenland, with more than three-quarters of the change north of $72^{\circ} \mathrm{N}$ (Fig. 2). Area change (loss) is greatest at the glaciers that have floating tongues: Zacharil Isstrøm, Jakobshavn, Petermann and Humboldt (Table 2; Fig. 2 inset). Cumulative area change at several glaciers through time is well represented by linear regression as indicated by correlation values in Table 2. Other glaciers, like Ryder glacier, exhibit a pattern of multi-annual advance that may be characterized by high linear fit correlation values. However, this advance between 2000 and 2005 was punctuated by a single major calving in 2006 and was followed again by advance each year during 2007-10 (Fig. 3). 
Table 1. Greenland glaciers surveyed in this study in years 2000-10. Regions are shown in Figure 1 (UD: Uummannaq district)

\begin{tabular}{|c|c|c|c|c|}
\hline Greenlandic name (non-native name) & $\begin{array}{l}\text { Latitude } \\
{ }^{\circ} \mathrm{N}\end{array}$ & $\begin{array}{c}\text { Longitude } \\
{ }^{\circ} \mathrm{W}\end{array}$ & $\begin{array}{c}\text { Width } \\
\text { km }\end{array}$ & Region \\
\hline (Daugaard Jensen) & 71.8 & 28.7 & 6.0 & E \\
\hline Kangerdlugssuaq & 68.6 & 33.0 & 8.6 & E \\
\hline (Ostenfeld) & 81.6 & 45.2 & 7.0 & $\mathrm{~N}$ \\
\hline (Ryder) & 81.3 & 49.9 & 8.0 & $\mathrm{~N}$ \\
\hline (Petermann) & 80.7 & 60.8 & 16.0 & $\mathrm{~N}$ \\
\hline (Humboldt) & 79.3 & 63.8 & 110.0 & $\mathrm{~N}$ \\
\hline (Nioghalvfjerdsbrì/79) & 79.5 & 21.2 & 62.6 & $\mathrm{NE}$ \\
\hline (Zacharil Isstrøm) & 78.9 & 21.6 & 22.8 & $\mathrm{NE}$ \\
\hline (Storstrømmen) & 76.8 & 22.7 & 27.8 & $\mathrm{NE}$ \\
\hline (D1/2cker Smith) & 76.2 & 60.9 & 4.3 & NW \\
\hline (Kong Oscar) & 75.9 & 59.7 & 4.1 & NW \\
\hline (Steenstrup) & 75.2 & 57.8 & 18.0 & NW \\
\hline (Hayes) & 74.9 & 56.9 & 10.7 & NW \\
\hline Nunatakassaap Sermia & 74.6 & 56.3 & 4.9 & NW \\
\hline (Upernavik) & 72.8 & 54.2 & 26.1 & NW \\
\hline (MidgÍrd) & 66.4 & 36.7 & 3.5 & SE \\
\hline (Helheim) & 66.3 & 38.2 & 5.5 & SE \\
\hline (Fenris) & 66.3 & 37.5 & 2.5 & SE \\
\hline Ikertivaq & 65.4 & 39.8 & 16.6 & SE \\
\hline Tingmjarmiut & 62.7 & 43.2 & 2.2 & SE \\
\hline Kangiata Nunata Sermia & 64.2 & 49.5 & 4.9 & SW \\
\hline Sermilik (Qagssimiut) & 61.0 & 46.9 & 2.2 & S \\
\hline Ingia & 72.0 & 52.5 & 3.2 & UD \\
\hline Umia?ma?ko & 71.7 & 53.2 & 3.5 & UD \\
\hline Rink & 71.7 & 51.5 & 4.5 & UD \\
\hline Kangerdlugssup Sermerssua & 71.4 & 51.3 & 4.7 & UD \\
\hline Kangerdluarssup Sermia & 71.2 & 51.4 & 3.6 & UD \\
\hline Sermeq Avangnardleq & 71.2 & 51.1 & 0.7 & UD \\
\hline Perdlerfiup Sermia & 70.9 & 50.9 & 3.1 & UD \\
\hline Sermeq Silardleq & 70.8 & 50.7 & 4.5 & UD \\
\hline Kangigdleq & 70.7 & 50.6 & 4.9 & UD \\
\hline (Lille) & 70.5 & 50.5 & 2.2 & UD \\
\hline (Store) & 70.4 & 50.4 & 5.3 & UD \\
\hline Sermeq Avannarleq Ilulissat & 69.3 & 50.3 & 2.5 & W \\
\hline Sermeq Kujatdleq (Jakobshavn Isbræ) & 69.2 & 49.5 & 6.8 & W \\
\hline
\end{tabular}

\section{North}

The largest single annual glacier area change evident in our survey is the loss at Petermann glacier between 3 and 5 August 2010. The glacier front lost $277 \mathrm{~km}^{2}$, effectively retreating $17 \mathrm{~km}$ between end-of-summer periods in 2009 and 2010 (Fig. 4). The 2010 front position is retreated compared with available observations from 1962, 1963 and 1992 (Zhou and Jezek, 2002), 1953, 1959 and 1978 (Higgins, 1990), and 1922 (Koch, 1926, 1928). A large rift upstream of the 2010 terminus suggests that the next major area loss could be $\sim 150 \mathrm{~km}^{2}$.

The largest net area change for a single glacier during this survey period is the $311 \mathrm{~km}^{2}$ loss at Humboldt Glacier. Practically all of the area changes have occurred in an embayment $\sim 12 \mathrm{~km}$ south of its northern limit where grounding-line retreat has been detected (Rignot and others, 2001). The second largest single annual area loss in our survey $\left(98.0 \mathrm{~km}^{2}\right)$ occurred at northern Humboldt in the 2001/02 end-of-summer interval. Comparing the 2000-10 decade of MODIS-derived calving-front positions with those from other sensors in Rignot and others (2001), northern Humboldt has been in retreat since at least the 1990s. Landsat imagery (courtesy of I. Howat of the Byrd Polar Research Center; http://glovis.usgs.gov) from 1975, 1999 and 2008 indicates an acceleration of area loss since

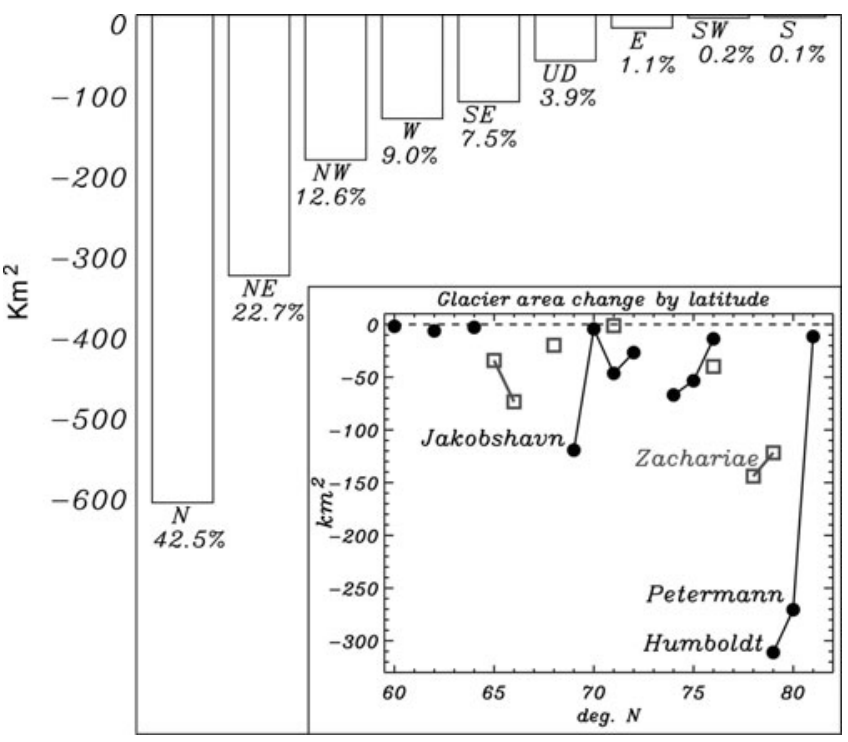

Fig. 2. Area change totals for Greenland regions during the period 2000-10 and their percent of the total. The inset illustrates total area change by $1^{\circ}$ latitude bins. West Greenland is represented by black and East Greenland by gray. Glaciers with the largest area changes are indicated. 
Table 2. Greenland glacier area and length change statistics 2000-10 sorted by the decadal area change rate. Regions are shown in Figure 1

\begin{tabular}{|c|c|c|c|c|c|c|c|c|}
\hline \multirow[t]{2}{*}{ Glacier } & \multirow[t]{2}{*}{ Region } & \multirow{2}{*}{$\begin{array}{c}\text { Area change } \\
\text { rate } \\
\mathrm{km}^{2} \mathrm{a}^{-1}\end{array}$} & \multirow{2}{*}{$\begin{array}{l}\text { Effective } \\
\text { length } \\
\text { change } \\
\mathrm{km}^{2} \mathrm{a}^{-1}\end{array}$} & \multirow[t]{2}{*}{$\begin{array}{c}\text { Time } \\
\text { correlation }\end{array}$} & \multirow{2}{*}{$\begin{array}{c}\text { Max. } \\
\text { annual } \\
\text { retreat } \\
\mathrm{km}^{2}\end{array}$} & \multirow[t]{2}{*}{ Year interval } & \multirow{2}{*}{$\begin{array}{c}\text { Max. } \\
\text { annual } \\
\text { advance } \\
\mathrm{km}^{2}\end{array}$} & \multirow[t]{2}{*}{ Year interval } \\
\hline & & & & & & & & \\
\hline Humboldt & $\mathrm{N}$ & -20.8 & -0.2 & -0.95 & -98.0 & $2001 / 02$ & 26.2 & 2003/04 \\
\hline Petermann & $\mathrm{N}$ & -18.7 & -1.2 & -0.56 & -277.2 & $2009 / 10$ & 22.0 & $2002 / 03$ \\
\hline Zachariì & NE & -14.1 & -0.6 & -0.91 & -67.0 & 2004/05 & 45.8 & $2006 / 07$ \\
\hline Nioghalvfjerdsbrì/79 & NE & -12.7 & -0.2 & -0.85 & -60.0 & 2004/05 & 8.4 & $2006 / 07$ \\
\hline Sermeq Kujatdleq (Jakobshavn) & W & -9.2 & -1.4 & -0.87 & -55.4 & $2002 / 03$ & 2.1 & 2006/07 \\
\hline Nunatakassaap Sermia (Alison) & NW & -5.8 & -1.2 & -0.91 & -18.9 & 2004/05 & 3.8 & 2008/09 \\
\hline Storstr $1 / 2 m m e n$ & NE & -4.3 & -0.2 & -0.98 & -9.2 & 2006/07 & 0.4 & 2001/02 \\
\hline MidgÍrd & SE & -3.6 & -1.0 & -0.94 & -14.5 & 2008/09 & 2.4 & $2001 / 02$ \\
\hline Ikertivaq & SE & -3.3 & -0.2 & -0.99 & -5.2 & $2006 / 07$ & -1.6 & $2007 / 08$ \\
\hline Upernavik C & NW & -2.9 & -0.8 & -0.93 & -10.8 & $2006 / 07$ & 6.0 & 2008/09 \\
\hline Helheim & SE & -2.5 & -0.5 & -0.80 & -10.7 & $2003 / 04$ & 13.0 & $2005 / 06$ \\
\hline Kangerdlugssuaq & $\mathrm{E}$ & -2.4 & -0.3 & -0.94 & -10.2 & $2004 / 05$ & 1.6 & 2001/02 \\
\hline Sermeq Avannarleq & W & -2.1 & -0.9 & -0.95 & -6.5 & $2006 / 07$ & 2.1 & 2008/09 \\
\hline Umiámáko & UD & -2.1 & -0.6 & -0.88 & -11.8 & $2004 / 05$ & 1.2 & $2005 / 06$ \\
\hline Ostenfeld & $\mathrm{N}$ & -1.9 & -0.3 & -0.81 & -20.6 & $2002 / 03$ & 5.6 & $2001 / 02$ \\
\hline D $1 / 2$ cker Smith & NW & -1.4 & -0.3 & -0.80 & -12.1 & $2004 / 05$ & 4.1 & $2005 / 06$ \\
\hline Ingia & UD & -1.3 & -0.4 & -0.45 & -29.4 & $2006 / 07$ & 13.5 & $2005 / 06$ \\
\hline Hayes & NW & -1.2 & -0.1 & -0.92 & -4.3 & $2002 / 03$ & 1.8 & $2003 / 04$ \\
\hline Kangerdluarssup Sermia & UD & -1.1 & -0.3 & -0.69 & -13.8 & $2002 / 03$ & 4.6 & $2004 / 05$ \\
\hline Ryder & $\mathrm{N}$ & -0.9 & -0.1 & -0.30 & -30.6 & $2005 / 06$ & 7.8 & $2002 / 03$ \\
\hline Rink & SE & -0.8 & -0.2 & -0.62 & -6.2 & $2005 / 06$ & 10.9 & $2003 / 04$ \\
\hline Sermeq Silardleq & UD & -0.7 & -0.2 & -0.66 & -9.1 & $2007 / 08$ & 8.6 & 2006/07 \\
\hline Tingmjarmiut & SE & -0.7 & -0.3 & -0.79 & -2.6 & $2001 / 02$ & 2.0 & $2000 / 01$ \\
\hline Kong Oscar & NW & -0.5 & -0.1 & -0.65 & -5.5 & $2002 / 03$ & 4.0 & $2000 / 01$ \\
\hline Kangiata Nunata Sermia & SW & -0.4 & -0.1 & -0.90 & -1.5 & $2006 / 07$ & 1.0 & $2000 / 01$ \\
\hline Fenris & SE & -0.3 & -0.1 & -0.84 & -2.9 & 2001/02 & 1.3 & $2005 / 06$ \\
\hline Sermilik (Qagssimiut) & $\mathrm{S}$ & -0.2 & -0.1 & -0.72 & -2.1 & 2008/09 & 1.1 & $2007 / 08$ \\
\hline Upernavik D & NW & -0.2 & 0.0 & -0.91 & -0.8 & $2004 / 05$ & 0.4 & $2001 / 02$ \\
\hline Kangerdlugssup Sermerssua & UD & -0.1 & 0.0 & -0.21 & -6.3 & $2004 / 05$ & 7.3 & 2003/04 \\
\hline Perdlerfiup Sermia & UD & -0.1 & 0.0 & -0.57 & -1.8 & $2004 / 05$ & 1.3 & 2003/04 \\
\hline Upernavik A & NW & -0.1 & 0.0 & -0.66 & -1.4 & $2004 / 05$ & 0.8 & $2003 / 04$ \\
\hline Lille & UD & -0.1 & 0.0 & -0.69 & -0.6 & $2004 / 05$ & 0.6 & $2002 / 03$ \\
\hline Sermeq Avangnardleq & UD & 0.1 & 0.1 & 0.85 & -0.2 & 2004/05 & 0.4 & $2003 / 04$ \\
\hline Kangigdleq & UD & 0.1 & 0.0 & 0.53 & -1.1 & $2007 / 08$ & 2.3 & 2003/04 \\
\hline Store & UD & 0.4 & 0.1 & 0.67 & -2.8 & 2008/09 & 4.9 & $2007 / 08$ \\
\hline Upernavik B & NW & 0.6 & 0.3 & 0.55 & -2.6 & 2008/09 & 7.0 & $2005 / 06$ \\
\hline
\end{tabular}

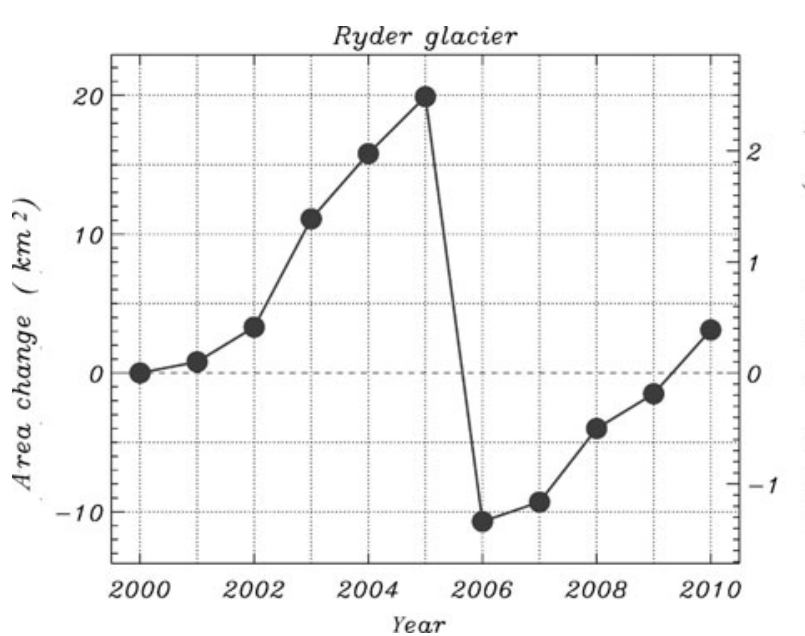

Fig. 3. Cumulative net area change at Ryder glacier for 2000-10.

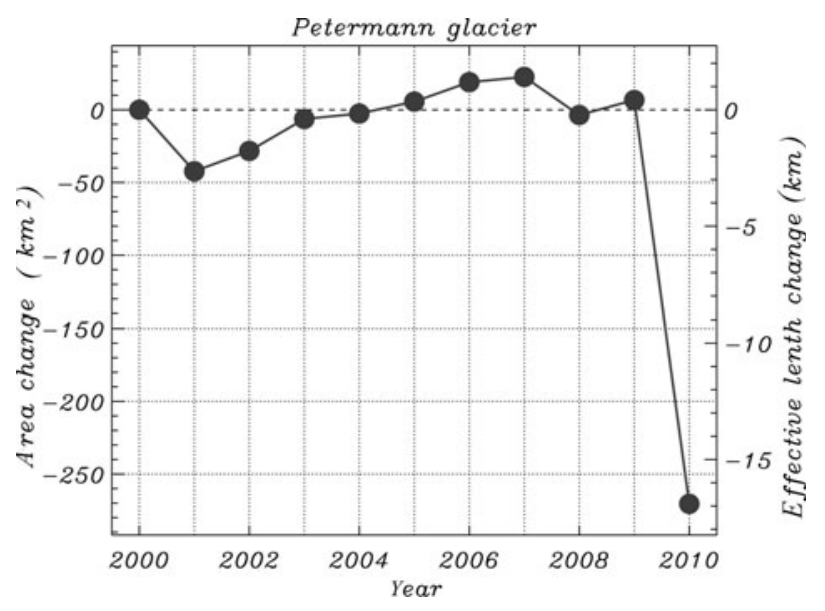

Fig. 4. Cumulative net area change at Petermann glacier for 2000-10. 


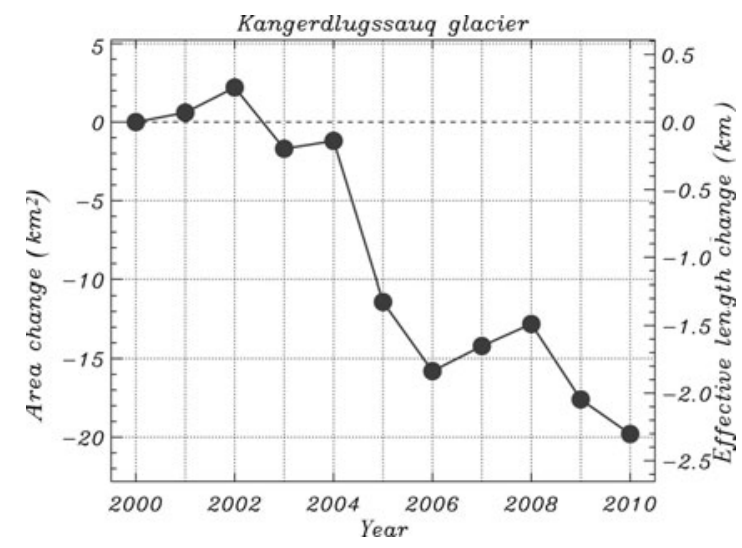

Fig. 5. Cumulative net area change at Kangerdlugssuaq glacier for 2002-10.

1975 and an ice stream flowing towards the present-day embayment.

\section{Northeast}

Zacharil Isstr $1 / 2 \mathrm{~m}$ terminates into an embayment packed with multi-year calf ice. Koch (1945) first referred to this ice mixture by the Inuit term sikussak. The term is used in East Greenland meaning 'ice-like ocean ice' and referring specifically to very old fast ice that has attained extreme thickness through age, low ocean heat flux (e.g. through being in a fjord) and/or high precipitation (again, for example, in a fjord) (P. Wadhams, cryolist communication). The Zacharil front area changes were small in the first 2 years of this survey, after which an area loss exceeding $14 \mathrm{~km}^{2} \mathrm{a}^{-1}$ ensued. Yet, uncertainty in this study is exemplified by the result of a large 2006/07 advance $\left(48 \mathrm{~km}^{2}\right.$; Table 2) that may not be real

At Nioghalvfjerdsbrì, also called the $79^{\circ} \mathrm{N}$ glacier, an overall retreat rate of $12.7 \mathrm{~km}^{2} \mathrm{a}^{-1}$ is evident. Although small for north Greenland, this change outranks the majority of the other glacier trends in our survey (Table 2).

Storstrømmen, considered a surge-type glacier (Reeh and others, 1994; Rignot and others, 2001), exhibits a smaller area loss rate of $4.3 \mathrm{~km}^{2} \mathrm{a}^{-1}$ (Table 2).

\section{East}

East Greenland glacier area changes are dominated by those at Kangerdlugssuaq (Fig. 5), one of the fastest-flowing and most productive of all glaciers in Greenland (Rignot and Kanagaratnam, 2006). The largest annual area loss at Kangerdlugssuaq was $10.2 \mathrm{~km}^{2}$ between the 2003 and 2004 end-of-summer periods. Area losses at this glacier add to a decadal retreat that is well represented by a linear fit $(R=$ -0.94 ) with a retreat rate of $2.4 \mathrm{~km} \mathrm{a}^{-1}$ (Table 2). Thomas and others (2000) find substantial thinning at this glacier during the 1990s and $<1 \mathrm{~km}$ retreat between 1966 and 1999 .

Daugaard Jensen glacier has undergone multi-annual advances and retreats of $<0.7 \mathrm{~km}$, with a cumulative area loss of $2.5 \mathrm{~km}^{2}$.

\section{Southeast}

The clearest pattern of ice area loss for southeast Greenland glaciers during the survey period is at MidgÍrd glacier, where an average frontal retreat of $1.0 \mathrm{~km} \mathrm{a}^{-1}$ is evident (Table 2). Other changes in southeast Greenland glacier length are in

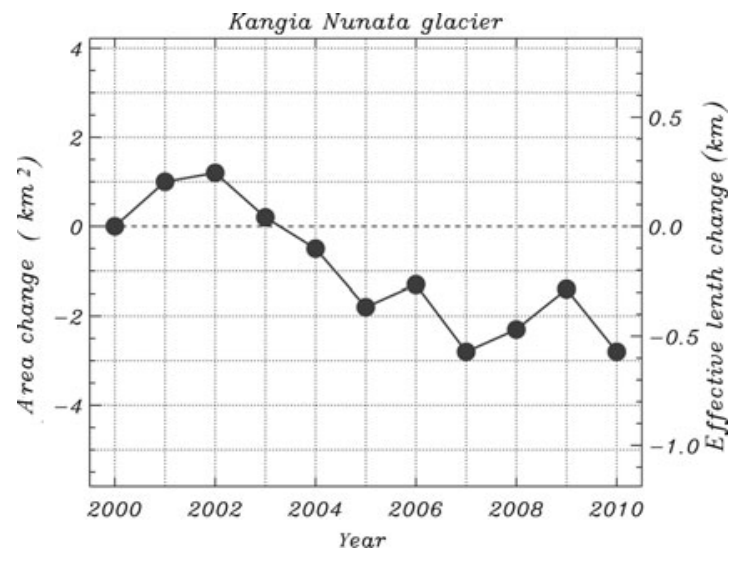

Fig. 6. Cumulative net area change at Kangia Nunata glacier for 2000-10.

the range -0.1 to $-0.5 \mathrm{~km} \mathrm{a}^{-1}$. Collectively, this region has accelerated in flow (Krabill and others, 2004; Luckman and others, 2006), synchronous with elevated air and oceanic temperatures (Howat and others, 2008). Straneo and others (2010) link the acceleration trigger with the delivery of warm waters into glacier fjords by wind-driven ocean currents.

\section{South and southwest}

The relatively few marine-terminating glaciers in this region exhibit relatively small area fluctuations. Kangiata Nunata Sermia (sermia means glacier or ice field in Greenlandic) retreated on average $0.1 \mathrm{~km} \mathrm{a}^{-1}$ in the period 2000-10 (Table 2; Fig. 6). Note the relatively small area/length changes compared with other glaciers in this study. Sermilik (Qagssimiut) advanced $1.1 \mathrm{~km}^{2}$ in the 2007/08 period followed by a $2.1 \mathrm{~km}^{2}$ retreat in the $2008 / 09$ period. The two surveyed glacier fronts from this region exhibit a net area loss of $5 \mathrm{~km}^{2}$ between 2000 and 2010 .

\section{West-central}

Area changes in west-central Greenland are dominated by Sermeq Kujatdleq (Jakobshavn Isbræ) (Table 2; Fig. 7). A peak annual area loss of $55 \mathrm{~km}^{2}$ occurred between 2002 and 2003 as the ice shelf of the glacier disintegrated. Prior to this the glacier front was relatively stable for about four decades (Weidick and Bennike, 2007). The 2003 area loss is recognized as resulting in a loss of flow resistance during a period of thinning (Thomas, 2004) and acceleration (Joughin and others, 2004). Retreat has continued since the loss of the ice shelf at a lesser rate of $0.6 \mathrm{~km} \mathrm{a}^{-1}$ in the $2005-10$ period. Between 2000 and 2010, we find a $100 \mathrm{~km}^{2}$ cumulative area loss and an effective glacier front retreat sum of $14.8 \mathrm{~km}$. Since the LIA maximum extent in 1850 (Weidick and Bennike, 2007), Sermeq Kujatdleq has retreated $>50 \mathrm{~km}$. Prior to this period, there is evidence of retreat upstream of the LIA ice front during the mid-Holocene thermal maximum (e.g. Weidick and Bennike, 2007).

Area losses at Sermeq Avannarleq are well represented by a linear fit (Table 2) and peaked at $6.5 \mathrm{~km}^{2}$ loss in the 2006/ 07 interval.

\section{Uummannaq district}

The greatest glacier area changes in the vicinity of the Uummannaq settlement have been at Umia?ma?ko glacier where an area loss of $15 \mathrm{~km}^{2}$ occurred in 2004 and 2005 


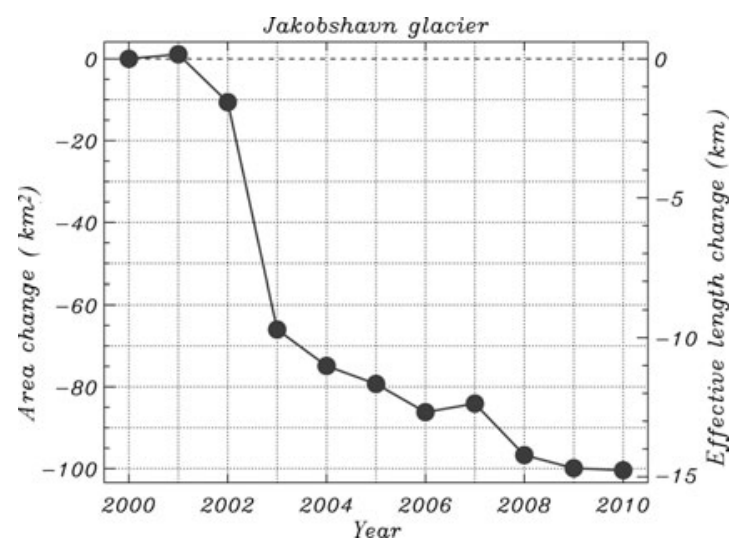

Fig. 7. Cumulative net area change at Jakobshavn glacier for 2000-10.

(Fig. 8). Umia?ma?ko advanced slightly by $1.2 \mathrm{~km}^{2}$ between 2005 and 2006 and continued to retreat, though at a much slower rate, through 2010 (Table 2). Rink and Store glaciers are the next most productive West Greenland calf ice producers (Rignot and Kanagaratnam, 2006; Weidick and Bennike, 2007). Store glacier's front position was $2.5 \mathrm{~km}$ advanced in 2010 from its 2000 position, with no apparent trend during this survey period. Rink glacier, like Store glacier, has a relatively stable front position, with an insignificant front position change in the 2000-10 period. The 11 surveyed Uummannaq district glaciers exhibit a net area loss of $51 \mathrm{~km}^{2}$ between 2000 and 2010 .

\section{Northwest}

Early last century, five ice-sheet outlet glaciers east of Upernavik settlement flowed together and produced a $\sim 100 \mathrm{~km}^{2}$ ice shelf that disintegrated in the 1931-49 period (Weidick, 1958). Today, the five now separated outlets, here named Upernavik A-E (see http://bprc.osu.edu/MODIS/ $? \mathrm{p}=40$ ) are discussed individually. Outlet $\mathrm{C}$ has changed most, losing $23.1 \mathrm{~km}^{2}$ since 2000 . This outlet accounts for $78 \%$ of the total net cumulative loss for the five glaciers. The retreat rate for $C$ is $0.8 \mathrm{~km} \mathrm{a}^{-1}, R=-0.93$ ). Upernavik outlets $\mathrm{A}, \mathrm{B}, \mathrm{D}$ and $\mathrm{E}$ have average length changes in the +0.3 to $-0.1 \mathrm{~km} \mathrm{a}^{-1}$ range.

The time-averaged glacier area changes in northwest Greenland are highest at Nunatakassaap Sermia (Fig. 9), referred to elsewhere (e.g. Joughin and others, 2010; Howat and Eddy, 2011) using the name of the bay in front of the

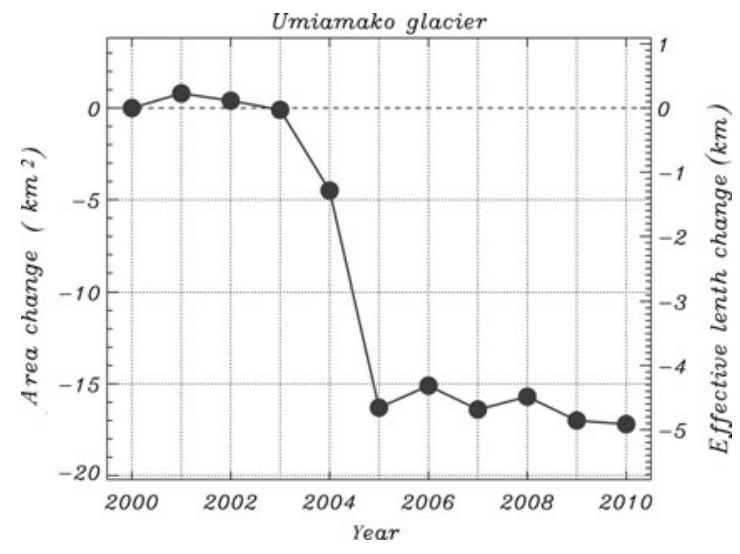

Fig. 8. Cumulative net area change at Umia?ma?ko Glacier for 2000-10.

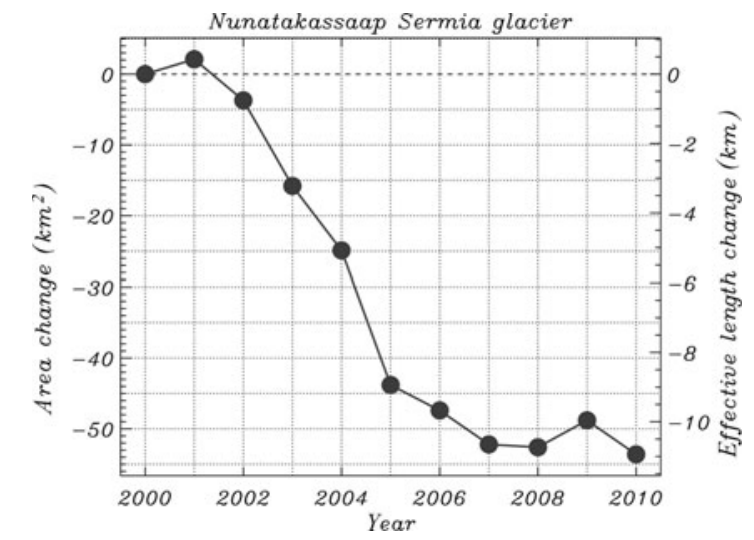

Fig. 9. Cumulative net area change at Nunatakassaap glacier for 2000-10.

glacier, i.e. Alison, with an annual effective area loss rate of $5.8 \mathrm{~km}^{2} \mathrm{a}^{-1}$ (Table 2) driven by a multi-year retreat spanning 2002-08 (see also Moon and Joughin, 2008).

\section{AREA CHANGE ANALYSIS}

\section{Stability of glaciers and ice shelves}

Considering all glaciers (including those with ice shelves) with interannual area changes of $<1.0 \mathrm{~km}^{2}$ to be 'stable', on average for the survey period $20 \%$ of glaciers advanced, $38 \%$ were stable and $42 \%$ retreated (Table 3 ). Thus, the count of glaciers retreating is, on average, twice that advancing. A yet larger distinction is that the average ratio of retreat and advance area is nine times the area gain. This ratio has extreme positive values annually associated with ice-shelf area losses. During the survey period, there was a $7 \%$ decrease in the fraction of glaciers and ice shelves that counted as stable, with the fraction retreating increasing 3\% and the fraction advancing increasing 6\%. The linear time correlation of these change statistics is greatest in magnitude for the increasing fraction of retreating glaciers, although, overall, the correlation coefficients do not suggest unequivocal trends. On an annual basis, 2003/04 had the smallest areal loss fraction, and 2009/10 had the greatest areal loss fraction.

The statistics are influenced by ice-shelf area changes; for example, the 2009/10 cumulative glacier areal retreat is eight times the advance, extreme in this year because of the extreme area loss at Petermann glacier. The loss/gain ratio for the designated ice shelves has a minimum value of 0.1 in $2006 / 07$ and 2008/09 and a maximum of 25.0 in 2010. The loss/gain ratio for glaciers is at a minimum of 0.8 in 2005/06, i.e. more gain than loss, and at a maximum of 66.7 in 2010 . No strong correlation $(>0.7)$ trend in this ratio is evident for ice shelves or glaciers.

\section{Ensemble patterns}

Because annual departures from the ensemble glacier trend are strongly influenced by the sporadic ice-shelf area losses, we compute trend and correlation statistics for glaciers and ice shelves separately. The six glaciers here classified as ice shelves are Petermann, Zachariì, Nioghalvfjerdsbrì/79, Ostenfeld, Jakobshavn and Ryder. The rates of cumulative area change for glaciers and ice shelves in the 2000-09 period are well represented by linear least-squares fits, $R=-0.98$ and $R=-0.94$, with average rates of -64 and 
Table 3. Annual collective glacier and ice-shelf area change statistics

\begin{tabular}{|c|c|c|c|c|c|c|c|}
\hline Period & $\begin{array}{c}\text { Number } \\
\text { advancing }\end{array}$ & $\begin{array}{c}\% \\
\text { advancing }\end{array}$ & Number stable & $\%$ stable & Number retreating & $\%$ retreating & $\begin{array}{l}\text { Area retreating/ } \\
\text { area advancing }\end{array}$ \\
\hline $2000 / 01$ & 7 & 17.9 & 22 & 56.4 & 10 & 25.6 & 7.8 \\
\hline 2001/02 & 9 & 23.1 & 17 & 43.6 & 13 & 33.3 & 5.2 \\
\hline $2002 / 03$ & 4 & 10.3 & 15 & 38.5 & 20 & 51.3 & 7.0 \\
\hline $2003 / 04$ & 13 & 33.3 & 11 & 28.2 & 15 & 38.5 & 1.9 \\
\hline $2005 / 06$ & 8 & 20.5 & 17 & 43.6 & 14 & 35.9 & 1 \\
\hline $2006 / 07$ & 12 & 30.8 & 11 & 28.2 & 16 & 41.0 & 1.5 \\
\hline $2007 / 08$ & 7 & 17.9 & 14 & 35.9 & 18 & 46.2 & 9.7 \\
\hline 2008/09 & 7 & 17.9 & 15 & 38.5 & 17 & 43.6 & 1.4 \\
\hline $2009 / 10$ & 3 & 7.7 & 18 & 46.2 & 18 & 46.2 & 28.3 \\
\hline Average & 7.7 & 19.7 & 14.9 & 38.2 & 16.4 & 42.1 & 7.3 \\
\hline Linear change & -2.2 & -5.8 & -2.8 & -7.3 & 5.1 & 13.1 & 10.0 \\
\hline Time correlation & -0.22 & -0.22 & -0.22 & -0.22 & 0.42 & 0.42 & 0.37 \\
\hline
\end{tabular}

$-41 \mathrm{~km}^{2} \mathrm{a}^{-1}$, respectively (Fig. 10a). By including 2010, the average ice-shelf loss rate is increased substantially by the $277 \mathrm{~km}^{2}$ Petermann glacier detachment, leading to an average decadal area loss rate of $53 \mathrm{~km}^{2} \mathrm{a}^{-1}$ and reduced goodness of fit $(R=-0.91)$. For glaciers, including 2010 leads to no change in the area loss rate and a slight increase in the linear fit correlation $(R=-0.99)$.

To evaluate the sensitivity to including 2010 or 2001 when the samples were either extreme or missing a few glaciers, we select different time intervals, 2001-10, 200210 and 2002-09, but find no consistent correlation $(R<0.2)$ between the glaciers and ice-shelf ensemble annual area change anomalies (see Fig. 10b). The only coincidence for the anomalies is in 2003.

\section{CONCLUSIONS}

This paper presents a description of a simple technique to assess Greenland glacier changes. Interannual area changes of marine-terminating outlets to the Greenland ice sheet are measurable using $(0.25 \mathrm{~km})$ MODIS imagery with an idealized precision of $1.0 \mathrm{~km}^{2}$. In most samples, the annually resolved area changes exceed this measurement precision. However, the absolute accuracy of the classification depends on decisions by the person who distinguishes between glacier ice, calf ice, sea ice, clouds, sea and land. In ideal cases when there is little or no sea ice the accuracy approaches the measurement precision. In marginal cases when images are blurry, have cloud contamination, shadows from land, and a less distinct calving front owing to increasing sea-ice concentration the absolute accuracy is low $\left(<10 \mathrm{~km}^{2}\right)$.

The cumulative pattern of area change from the 39 glaciers surveyed indicates a linear $(R=-0.91$ to -0.94$)$ and geographically widespread retreat pattern. The total net cumulative area change of the surveyed glaciers from the end of summer 2000 to 2010 is $-1368 \mathrm{~km}^{2}$, corresponding to an annual areal loss of $137 \mathrm{~km}^{2} \mathrm{a}^{-1}$ including the Petermann glacier detachment in 2010. Excluding the Petermann calving in 2010, the 2000-09 deglaciation rate is $102 \mathrm{~km}^{2} \mathrm{a}^{-1}$, well represented by a linear fit $(R=-0.98)$. More than three-quarters of the area losses are from north Greenland glaciers (north of $72^{\circ} \mathrm{N}$ ). The total width of marine-terminating front in our survey $(424 \mathrm{~km})$ retreated on average $3.2 \mathrm{~km}$ in the survey period.
Over the survey decade (2000-10), on average, the count of glaciers retreating is twice that advancing. A yet larger distinction is in terms of area, with the ratio of retreat and advance, on average, seven times the gain. We find no correlation $(R<0.2)$ between the glaciers and ice-shelf ensemble annual area change anomalies.

The area change data from this study are posted at http://bprc.osu.edu/ jbox/data/GAC/

\section{ACKNOWLEDGEMENTS}

The initial development of our survey was supported by US National Science Foundation (NSF) Office of Polar Programs award 0531306. The research was subsequently supported by The Ohio State University's Climate Water and Carbon Program. We thank two anonymous reviewers, I. Howat and A. Mnchow for constructive comments, and T. Haran at the US National Snow and Ice Data Center, Boulder, Colorado, for assistance with MODIS data. Insight into the Petermann glacier front history was gained through discussion with H. Melling and K. Falkner. K. Markoff provided some very useful IDL graphics routines. This is Byrd Polar Research Center contribution No. 1398.
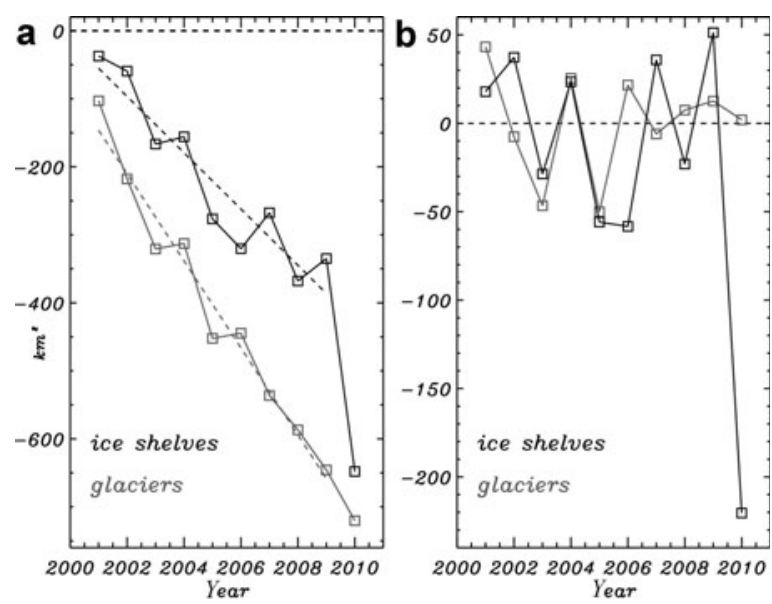

Fig. 10. (a) Cumulative net annual area changes for the 33 widest marine-terminating glaciers and six ice-shelf outlets to the Greenland ice sheet. (b) Anomalies from the linear fit excluding the extreme year 2010 for ice shelves. 


\section{REFERENCES}

Amundson, J.M., M. Fahnestock, M. Truffer, J. Brown, M.P. Lüthi and R.J. Motyka. 2010. Ice mélange dynamics and implications for terminus stability, Jakobshavn Isbræ, Greenland. J. Geophys. Res., 115(F1), F01005. (10.1029/2009JF001405.)

Box, J.E. and 8 others. 2006. Greenland ice sheet surface mass balance variability $(1988-2004)$ from calibrated polar MM5 output. J. Climate, 19(12), 2783-2800.

Box, J.E., L. Yang, D.H. Bromwich and L.-S. Bai. 2009. Greenland ice sheet surface air temperature variability: 1840-2007. J. Climate, 22(14), 4029-4049.

De Angelis, H. and P. Skvarca. 2003. Glacier surge after ice shelf collapse. Science, 299(5612), 1560-1562.

Higgins, A.K. 1991. North Greenland glacier velocities and calf ice production. Polarforschung, 60(1), 1-23.

Holland, D.M., R.H. Thomas, B. de Young, M.H. Ribergaard and B. Lyberth. 2008. Acceleration of Jakobshavn Isbræ triggered by warm subsurface ocean waters. Nature Geosci., 1(10), 659-664.

Howat, I.M. and A. Eddy. 2011. Multidecadal retreat of Greenland's marine-terminating glaciers. J. Glaciol., 57(203), 389-396.

Howat, I.M., I. Joughin, S. Tulaczyk and S. Gogineni. 2005. Rapid retreat and acceleration of Helheim Glacier, east Greenland. Geophys. Res. Lett., 32(22), L22502. (10.1029/2005GL024737.)

Howat, I.M., I.R. Joughin and T.A. Scambos. 2007. Rapid changes in ice discharge from Greenland outlet glaciers. Science, 315(5818), 1559-1561.

Howat, I.M., I. Joughin, M. Fahnestock, B.E. Smith and T. Scambos. 2008. Synchronous retreat and acceleration of southeast Greenland outlet glaciers 2000-2006: ice dynamics and coupling to climate. J. Glaciol., 54(187), 646-660.

Howat, I.M., J.E. Box, Y. Ahn, A. Herrington and E.M. McFadden. 2010. Seasonal variability in the dynamics of marine-terminating outlet glaciers in Greenland. J. Glaciol., 56(198), 601-613.

Joughin, I., W. Abdalati and M.A. Fahnestock. 2004. Large fluctuations in speed on Greenland's Jakobshavn Isbræ glacier. Nature, 432(7017), 608-610.

Joughin, I. and 8 others. 2008a. Ice-front variation and tidewater behavior on Helheim and Kangerdlugssuaq Glaciers, Greenland. J. Geophys. Res., 113(F1), F01004. (10.1029/2007JF000837.)

Joughin, I., S.B. Das, M.A. King, B.E. Smith, I.M. Howat and T. Moon. 2008b. Seasonal speedup along the western flank of the Greenland Ice Sheet. Science, 320(5877), 781-783.

Joughin, I., B.E. Smith, I.M. Howat, T. Scambos and T. Moon. 2010. Greenland flow variability from ice-sheet-wide velocity mapping. J. Glaciol., 56(197), 415-430.

Koch, L. 1926. Report on the Danish Bicentenary Jubilee Expedition North of Greenland 1920-23. Medd. Grønl., 70(1), 1-232.

Koch, L. 1928. Contributions to the glaciology of North Greenland. Medd. Grønl., 65(2), 181-464.

Koch, L. 1945. The east Greenland ice. Medd. Grønl., 130(3), 1-374.

Krabill, W. and 12 others. 2004. Greenland Ice Sheet: increased coastal thinning. Geophys. Res. Lett., 31(24), L24402. (10.1029/ 2004GL021533.)

Levitus, S., J.I. Antonov, T.P. Boyer, R.A. Locarnini, H.E. Garcia and A.V. Mishonov. 2009. Global ocean heat content 1955-2008 in light of recently revealed instrumentation problems. Geophys. Res. Lett., 36(7), L07608. (10.1029/2008GL037155.)

Luckman, A., T. Murray, R. de Lange and E. Hanna. 2006. Rapid and synchronous ice-dynamic changes in East Greenland. Geophys. Res. Lett., 33(3), L03503. (10.1029/2005GL025428.)

Meier, M.F. and A. Post. 1987. Fast tidewater glaciers. J. Geophys. Res., 92(B9), 9051-9058.

Moon, T. and I. Joughin. 2008. Changes in ice front position on Greenland's outlet glaciers from 1992 to 2007. J. Geophys. Res., 113(F2), F02022. (10.1029/2007JF000927.)

Motyka, R.J., L. Hunter, K.A. Echelmeyer and C. Connor. 2003. Submarine melting at the terminus of a temperate tidewater glacier, LeConte Glacier, Alaska, U.S.A. Ann. Glaciol., 36, 57-65.

Nick, F.M., A. Vieli, I.M. Howat and I. Joughin. 2009. Large-scale changes in Greenland outlet glacier dynamics triggered at the terminus. Nature Geosci., 2(2), 110-114.

Pfeffer, W.T., J.T. Harper and S. O'Neel. 2008. Kinematic constraints on glacier contributions to 21 st-century sea-level rise. Science, 321(5894), 1340-1343.

Reeh, N., C.E. Bøggild and H. Oerter. 1994. Surge of Storstrømmen, a large outlet glacier from the inland ice of north-east Greenland. Grønl. Geol. Unders. Rapp., 162, 201-209.

Reeh, N., H.H. Thomsen, A.K. Higgins and A. Weidick. 2001. Sea ice and the stability of north and northeast Greenland floating glaciers. Ann. Glaciol., 33, 474-480.

Rignot, E. and S.S. Jacobs. 2002. Rapid bottom melting widespread near Antarctic ice sheet grounding lines. Science, 296(5575), 2020-2023.

Rignot, E. and P. Kanagaratnam. 2006. Changes in the velocity structure of the Greenland Ice Sheet. Science, 311(5673), 986990.

Rignot, E., S. Gogineni, I. Joughin and W. Krabill. 2001. Contribution to the glaciology of northern Greenland from satellite radar interferometry. J. Geophys. Res., 106(D24), 34,007-34,019.

Rignot, E., J.E. Box, E. Burgess and E. Hanna. 2008. Mass balance of the Greenland ice sheet from 1958 to 2007. Geophys. Res. Lett., 35(20), L20502. (10.1029/2008GL035417.)

Rignot, E., M. Koppes and I. Velicogna. 2010. Rapid submarine melting of the calving faces of West Greenland glaciers. Nature Geosci., 3(3), 187-191.

Shepherd, A., A. Hubbard, P. Nienow, M. King,M. McMillan and I. Joughin. 2009. Greenland ice sheet motion coupled with daily melting in late summer. Geophys. Res. Lett., 36(1), L01501. (10.1029/2008GL035758.)

Sohn, H.G., K.C. Jezek and C.J. van der Veen. 1998. Jakobshavn Glacier, West Greenland: 30 years of spaceborne observations. Geophys. Res. Lett., 25(14), 2699-2702.

Solomon, S. and 7 others, eds. 2007. Climate change 2007: the physical science basis. Contribution of Working Group I to the Fourth Assessment Report of the Intergovernmental Panel on Climate Change. Cambridge, etc., Cambridge University Press.

Straneo, F. and 7 others. 2010. Rapid circulation of warm subtropical waters in a major glacial fjord in East Greenland. Nature Geosci., 3(33), 182-186.

Thomas, R.H. 2004. Force-perturbation analysis of recent thinning and acceleration of Jakobshavn Isbræ, Greenland. J. Glaciol., 50(168), 57-66.

Thomas, R.H. and 8 others. 2000. Substantial thinning of a major east Greenland outlet glacier. Geophys. Res. Lett., 27(9), 1291-1294.

Van de Wal, R.S.W. and 6 others. 2008. Large and rapid meltinduced velocity changes in the ablation zone of the Greenland Ice Sheet. Science, 321(5885), 111-113.

Weidick, A. 1958. Frontal variations at Upernaviks Isström in the last 100 years. Medd. Dansk Geol. Fören. Köbenhavn, 14(1), 52-60.

Weidick, A. and O. Bennike. 2007. Quaternary glaciation history and glaciology of Jakobshavn Isbræ and the Disko Bugt region, West Greenland: a review. Copenhagen, Geological Survey of Denmark and Greenland. (GEUS Bulletin 14.)

Zhou, G. and K.C. Jezek. 2002. Satellite photograph mosaics of Greenland from the 1960s era. Int. J. Remote Sens., 23(6), 1143-1159.

Zwally, H.J., W. Abdalati, T. Herring, K. Larson, J. Saba and K. Steffen. 2002. Surface melt-induced acceleration of Greenland ice-sheet flow. Science, 297(5579), 218-222.

Zweng, M.M. and A. Münchow. 2006. Warming and freshening of Baffin Bay, 1916-2003. J. Geophys. Res., 111(C7), C07016. (10.1029/2005JC003093.) 